\title{
Immunological responses of procambarus clarkii to MAP30 and its efficacy to protect shrimp against white spot syndrome virus and vibrio alginolyticus
}

\begin{abstract}
Momordica anti-HIV protein 30 (MAP30) is a novel antiviral, antitumor, and antimicrobial protein, and then we revealed that recombinant MAP30 (rMAP30) regulated the activity of immunological factors, phenoloxidase, and superoxide dismutase in hemolymph. The antimicrobial activity of rMAP30 was determined in vitro. Moreover, rMAP30 also facilitated the subsequent clearance of Vibrio alginolyticus in Procambarus clarkii, Challenge experiments with WSSV (100\% mortality and 70\% mortality) demonstrated significant protection in crayfish with relative survival rate $60 \%$ and $85,5 \%$, respectively. By quantitative RT-PCR analysis, rMAP30 prolonged the survival of WSSV-infected shrimp, and inhibited WSSV replication in Procambarus clarkii. In conclusion, result of this study suggest that rMAP30 may be a candidate for the prevention of WSSV and vibriosis.
\end{abstract}

Keywords: MAP30, White spot syndrome virus, V.alginolyticus, P.clarkii, Immunological factors
Volume 6 Issue 4 - 2017

\author{
Xiao Lin Meng, Nan Wang, Ming Xiang Meng, \\ Mei NaWang \\ State Key Laboratory of Virology College of Life Sciences \\ Wuhan University China
}

Correspondence: Xiao Lin Meng State Key Laboratory of Virology College of Life Sciences Wuhan University China, Tel 86-13607192748, Email mengaxiolin8@hotmail.com

Received: September 21, 2017 | Published: September 25, 2017
Abbreviations: MAP30, Momordica Anti-HIV Protein 30; rMAP30, Recombinant MAP30; WSSV, White Spot Syndrome Virus; PO, Phenoloxidase; L-dopa; L-3, 4-Dihydroxy-Phenylalanine; SOD, Superoxide Dismutase; P. clarkii, Procambarus Clarkii

\section{Introduction}

White spot syndrome (WSS), caused mainly by the white spot syndrome virus (WSSV). ${ }^{1}$ is a major disease in crustaceans, particularly for shrimp. ${ }^{2-5}$ Since its discovery in Taiwan in $1992 .{ }^{6}$ the virus has spread rapidly causing significant losses to shrimp production almost all over the world. ${ }^{7-11}$ Shrimp infected with WSSV, principally display white spots or patches embedded in the exoskeleton and epidermis. ${ }^{12}$ and show a cumulative mortality of upto $100 \%$ within 10 days in commercial shrimp farms. ${ }^{13}$ Previous strategies to prevent and control WSSV, generally included an improvement of environmental conditions, stocking up of specific pathogen-free or pathogen-resistant post-larvae, induction of nonspecific antiviral responses to antiviral drugs or immunostimulants. ${ }^{14-16}$ neutralization of antibodies. ${ }^{17-20}$ specific immunization by vaccines. ${ }^{21-26}$ and suppression of the virus with RNAi technology. ${ }^{27-31}$

Momordica anti-HIV protein 30 (MAP30) is a novel antiviral, antitumor, and antimicrobial protein from the plant species Momrodica charantia. ${ }^{32}$ This protein exhibits antiviral activity against the AIDS virus HIV- $1 .{ }^{32}$ the HSV.$^{33}$ and the HHV8 viruses. ${ }^{34}$ Momordica anti-HIV protein 30 (MAP30) also exhibits antitumor activity against brain glioblastoma, breast carcinoma, epidermoid carcinoma, liver hepatoma, myeloma, neuroblastoma, prostrate carcinoma, and melanoma as well as AIDS-related lymphoma. ${ }^{35-38}$ In the current study, we determined the new antiviral activity of the protein MAP30 against WSSV, and the antimicrobial activity against Vibrio alginolyticus in Procambarus clarkii. We also analyzed the immunological parameters in P. clarkii to detect the induction of the humoral immune reaction by MAP30.This protein could be used to develop novel strategies for WSSV and vibrios infection.

\section{Materials and methods}

\section{Materials}

Procambarus clarkii (approximately 20-30 g per sample) was purchased from a local market in Wuhan, Hubei Province, China, maintained in fiberglass tanks at room temperature $\left(25 \pm 1{ }^{\circ} \mathrm{C}\right)$, and fed with artificial pellet feed, twice a day. Prior to the experiments, the crayfish were screened for the presence of WSSV by PCR and cultured for 2 weeks before treatment, to ensure they were healthy and WSSV-free. WSSV was purified from infected $P$. clarkii according to a previously described method. ${ }^{39}$ Vibrio alginolyticus were conserved in our laboratory.

\section{In vivo viral titration}

To determine the amount of virus required to achieve mortality greater than $50 \%$ and $90 \%$ in 10 days, respectively, the virus stock was titrated by in vivo infection experiments. Thirty P. clarkii were injected with $100 \mu \mathrm{l}$ of different dilutions of WSSV stocks in sterile TN buffer (20 mM Tris- $\mathrm{HCl}, 0.4 \mathrm{M} \mathrm{NaCl}, \mathrm{pH}$ 8.5). The negative control was injected with TN buffer alone. Mortality was recorded twice a day, and the dead shrimp were examined by PCR to further confirm infection with WSSV.

\section{Recombinant MAP30 (rMAP30) synthesis}

MAP30 was synthesized (Generay Biotech Co., Ltd., China) based on the mature amino acid sequence reported by Lee-Huang (accession number S79450), with an E. coli codon bias. The synthesized MAP30 gene was cloned into pGH-T (Generay Biotech Co., Ltd., China), and the resulting recombinant plasmid was named pGH-MAP30.

\section{Construction of the expression plasmid}

Full-length synthetic MAP30 was amplified with polymerase chain reaction (PCR) from pGH-MAP30 with specific primers $\mathrm{PF}$ (5'-CGCGGATCCATGGATGTTAACTTCGATTTGTC-3') and PR (5'-CGCGAGCTCATTCACAACAGATTCCCCAAG-3'). BamHI 
and SacI sites were designed at the ends of each primer, respectively. The PCR product was digested with BamHI and SacI (New England BioLabsO Inc, MA, USA) and then inserted into the pET-28a (+) vector (EMD Millipore, MA, USA). The recombinant plasmid (pET28a-MAP30) was transformed into E. coli BL21 (DE3) (EMD Millipore, MA, USA). Positive transformants were identified by PCR with the PF and PR primers and sequenced in both directions.

\section{Expression and purification of recombinant MAP30 (rMAP30) in E.coli}

A single $E$. coli BL21 (DE3) colony containing pET28a-MAP30 was cultured overnight at $37^{\circ} \mathrm{C}$ in LB liquid media containing kanamycin $(30 \mathrm{ug} / \mathrm{ml})$. This culture was transferred to $200 \mathrm{ml}$ of fresh media and incubated for $2 \mathrm{~h}$ at $37^{\circ} \mathrm{C}$ until the OD 600 of the culture reached a value of 0.6 . The culture was then induced with $0.5 \mathrm{mM}$ IPTG overnight at $18^{\circ} \mathrm{C}$. MAP30 was purified using Ni-NTA super flow agarose (QIAGEN, Hilden, Germany), according to the manufacturer's protocol. The eluates were dialyzed with PBS and then concentrated by polyethylene glycol $(\mathrm{MW}=20000)$ in a bag filter. The protein concentration was determined using the Bradford protein assay. The purified protein was analyzed by $12 \%$ SDS-PAGE and confirmed by western blot.

\section{In vivo anti-WSSV assay}

The anti-WSSV activity of MAP30 was tested in healthy $P$. clarkii shrimps challenged with WSSV. 8 groups of healthy shrimps were divided evenly into two sets (4 groups per set and 30 shrimps per group). For each set, the first group was injected intramuscularly with $100 \mu \mathrm{L}$ sterile TN buffer as a negative control. The second group was injected with WSSV as a positive control, the third group was injected with WSSV pre-incubated with BSA, and the fourth group was injected with WSSV pre-incubated with $200 \mu \mathrm{g} / \mathrm{mL}$ rMAP30 for 20 min at $25^{\circ} \mathrm{C}(100 \mu \mathrm{L}$ per shrimp)

The first set of shrimps was challenged with an injection of WSSV with a dilution that produces $50 \%$ mortality. The second set of shrimps were injected with WSSV with a dilution that produces $90 \%$ mortality. Shrimp mortality was monitored daily for 15 days, and the dead shrimp were examined by PCR to confirm the infection with WSSV. Protection against WSSV, after the challenge, was calculated as the relative percent survival (RPS). RPS $=(1-$ mortality of test group/mortality of control group) $\times 100$.

\section{WSSV quantification by qPCR}

Three individuals were sampled at $72 \mathrm{~h}$ post injection from the $90 \%$ mortality set. The $90 \%$ mortality set contains the WSSV singleinfection group, the WSSV group that is pre-incubated with BSA, and the WSSV group that is pre-incubated with MAP30. The gills were sampled for in vivo WSSV replication analysis. DNA extraction, standard plasmid preparation, and the quantification of WSSV copy number by qPCR were performed as described by Kumar DR et al. ${ }^{39}$ The qRT-PCR was carried out using the THUNDERBIRD SYBR qPCR Mix (TOYOBO Co. Ltd., Osaka, Japan) and absolute quantification was performed using the ABI7500 machine (Applied Biosystems, Thermo Fisher Scientific Inc., MA, USA). The sequences of the primers used in the qPCR were (F: 5-GCTCCAACACCTCCTCCTTCAC-3; R: 5-CTCGGTCTCAGTGCCAGAGTAGG-3). All the samples were tested in triplicate, and three samples were taken from each group. Distilled water replaced the extracted DNA as a negative control for each new run. The virus concentration was converted to copy number per milligram tissue.

\section{Analysis of immunological parameters}

To detect the induction of the humoral immune reaction by MAP30, MAP30 (50 $\mu \mathrm{g}$ in $100 \mu \mathrm{L}$ of PBS), BSA (50 $\mu \mathrm{g}$ in $100 \mu \mathrm{L}$ of PBS), and PBS were injected into P. clarkii, respectively. At different time points post injection, the hemolymph samples collected from each group, were analyzed for various immunological parameters.

\section{Phenoloxidase (PO) activity assay}

The hemolymph PO activity was detected using L-3, 4-dihydroxyphenylalanine (L-dopa) dissolved in water according to the procedures outlined by Wang et $\mathrm{al}^{40}$ Briefly, $2 \mathrm{mg}$ of total hemolymph proteins in $435 \mu \mathrm{L}$ of Tris- $\mathrm{HCl}(10 \mathrm{mM}$, PH 8.0$)$ were mixed with $65 \mu \mathrm{L}$ of freshly prepared L-dopa ( $3 \mathrm{mg} / \mathrm{mL}$ in water). Following incubation at room temperature for $30 \mathrm{~min}, 500 \mu \mathrm{L}$ of $10 \%(\mathrm{v} / \mathrm{v})$ acetic acid was added to the mixture, and the $\mathrm{PO}$ activity was measured by monitoring the absorbance at $490 \mathrm{~nm}$. The PO activity was recorded as $\Delta \mathrm{A} 490$ per $\mathrm{mg}$ total protein per min.

\section{Superoxide dismutase (SOD) activity assay}

The SOD activity was determined using an SOD kit (Nanjing Jiancheng Bioengineering Institute, Nanjing, China).

\section{Antioxidant capacity in vitro}

The antioxidant capacity of MAP30 was evaluated by a method based on the Fenton reaction, described by Halliwell and Gutteridge .$^{41}$ and Desmarchelier et al. ${ }^{42}$ but with modifications. This method detects antioxidants classified as scavengers to hydroxylate free radicals. Briefly, various concentrations of MAP30 $(2,4,8,16,32$, $64,128,256,500,1000,2000 \mu \mathrm{g} / \mathrm{mL}$ ) were added to the reaction medium (Fenton reaction) containing $\mathrm{FeSO}_{4}(5 \mathrm{mM})$, crystal violet (2 $\mathrm{mM}), \mathrm{H}_{2} \mathrm{O}_{2}(100 \mathrm{mM})$, and Tris- $\mathrm{HCl}(50 \mathrm{mM}, \mathrm{pH} 5.5)$. The mixture was incubated at $25^{\circ} \mathrm{C}$ for $10 \mathrm{~min}$, and then measured at $588 \mathrm{~nm}$ (As). The control was prepared by the same method, where MAP30 was replaced with BSA. Radical scavenging activity was calculated as follows: $\operatorname{RSA}(\%)=[(\mathrm{As}-\mathrm{Ab}) /(\mathrm{A} 0-\mathrm{Ab})] \times 100$, where $\mathrm{A} 0$ was the absorbance of the reaction medium before proteins were added, As was the absorbance of the reaction medium after each of the different concentrations of MAP30 was added, and Ab was the absorbance of the reaction medium without $\mathrm{Fe} 2+$ and $\mathrm{H}_{2} \mathrm{O}_{2}$.

\section{Topological inactivation activity of rMAP30}

To identify the topological inactivation activity of rMAP30, the reaction was carried out with a final volume of $10 \mu \mathrm{L}$ containing either supercoiled Litmus38i or WSSV genome DNA as a substrate. The Litmus38i and the WSSV genome DNA were each incubated with MAP30 at $37^{\circ} \mathrm{C}$ for $60 \mathrm{~min}$. In the presence of suitable enzymatic conditions, the products were analyzed using electrophoresis in a $1 \%$ agarose gel in Tris-phosphate buffer with Tris-Acetate-EDTA buffer. The gel was stained with ethidium bromide for visual documentation by using short wavelength UV light.

\section{Determination of the antimicrobial effects of rMAP30 in vitro}

The antimicrobial test was carried out according to the method developed by Seydim and Sarikus. ${ }^{43}$ with some modifications. The zone of inhibition assay in the solid media was used to determine the antimicrobial effects of rMAP30 against $V$. alginolyticus. During the test, paper disks containing either antibiotic or PBS or MAP30, were placed on a lawn of bacteria in plates containing LB agar medium and incubated at $37^{\circ} \mathrm{C}$ overnight. The plates were examined to determine 
the inhibition zone of the disks, and the diameter of the zone was measured.

\section{V. alginolyticusclearance test in shrimp}

The assay was conducted according to previously described methods. ${ }^{44}$ Briefly, V. alginolyticus $(2 \times 108 \mathrm{CFU})$ was incubated with PBS, BSA $(200 \mu \mathrm{g} / \mathrm{mL})$, or MAP30 $(200 \mu \mathrm{g} / \mathrm{mL})$ at $28^{\circ} \mathrm{C}$ for 30 min, respectively. After incubation, the samples $(100 \mu \mathrm{L}$ each) were injected into the abdominal segment of the shrimp (divided into 3 groups). At every time point post injection $(2 \mathrm{~min}, 30 \mathrm{~min}, 1 \mathrm{~h}$, and $2 \mathrm{~h})$, hemolymph $(100 \mu \mathrm{L})$ was collected from the ventral sinus (3 shrimps for each sample). After serial dilutions with PBS, the sample $(50 \mu \mathrm{L})$ was plated onto thiosulphate-citrate-bile salts-sucrose agar TCBS plates. The plates were incubated overnight at $37^{\circ} \mathrm{C}$, and the bacterial clones on the plate were counted. The number of bacteria in $100 \mu \mathrm{L}$ hemolymph was determined. The data were subjected to statistical analysis using an unpaired t-test. Significant differences were accepted at $\mathrm{p}<0.05$.

\section{Results and discussion}

\section{Expression and purification of MAP30}

Recombinant MAP30 (rMAP30) expression analysis was performed by SDS-PAGE and a band around $30 \mathrm{kDa}$ was observed in the sample collected at $12 \mathrm{~h}$ post induction of $0.5 \mathrm{mM}$ IPTG (Figure 1). The corresponding band was not observed in the cell sample obtained prior to induction. The recombinant protein was identified in the soluble form and was present in the supernatant. The protein was purified by the Ni-NTA superflow agarose column from the culture supernatant and was examined by SDS-PAGE. Western blot analysis was used to confirm the expression of the recombinant MAP30 protein.

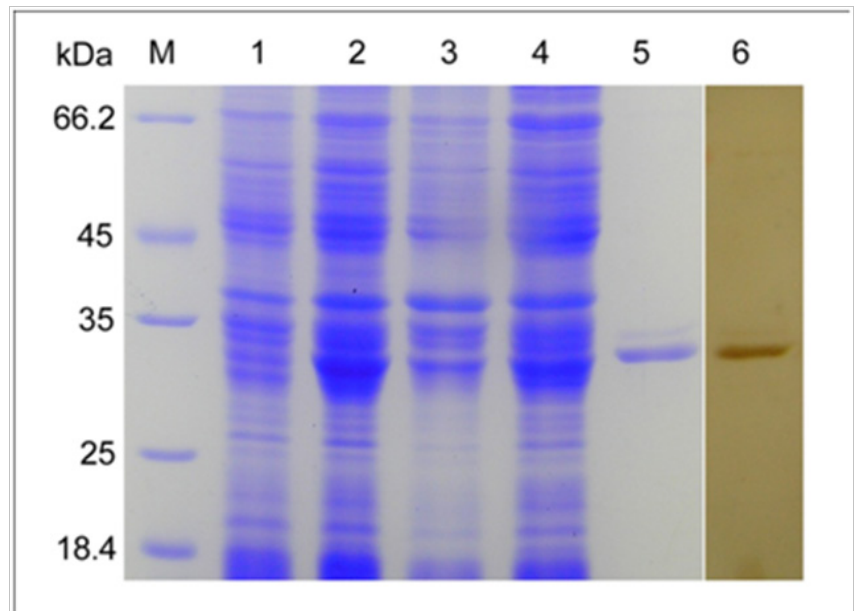

Figure I Expression and purification of rMAP30 in E.coli BL2I (DE3). Lane $M$, protein molecular marker. Lane I and 2, total protein from E.coli BL2I (DE3)/PET-28a (+)-MAP30 before and after IPTG induction. Lane 3 and 4, sediment and supernatant after induction, ultrasonication, and centrifugation. Lane 5, purified recombinant MAP30. Lane 6, purified rMAP30 was analyzed by western blotting with anti-MAP30 lgGs.

\section{Anti-WSSV activity in vivo}

To determine whether rMAP30 has anti-WSSV activity in shrimps in vivo, the shrimps were intramuscularly injected with sterile TN (negative control), WSSV (positive control), and WSSV pre-incubated with rMAP30 or BSA.
In the first set (70\% mortality, WSSV injected), mortality was first observed at 3 days post infection in the positive control group and the BSA-treated WSSV group, while mortality was observed only 3 days later in the rMAP30 group. After 15 days, the group that was treated with rMAP30 showed significantly lower cumulative mortality $(9.96 \%)$ compared with the positive control (70\% mortality) (Figure 2A).

(A)

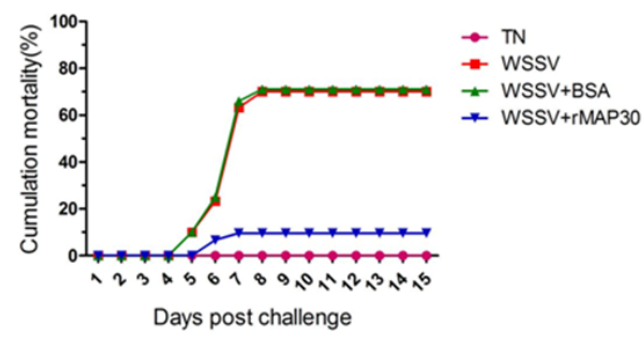

(B)

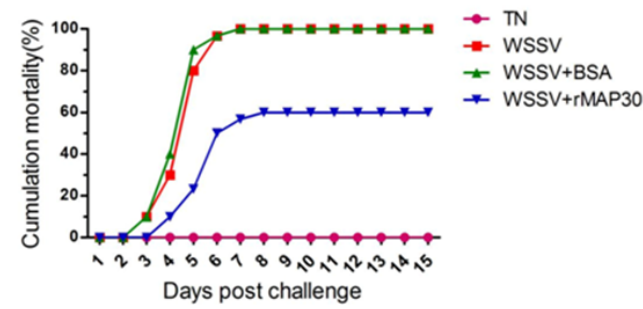

Figure 2 Recombinant MAP30 (rMAP30) anti-WSSV activity in vivo. Shrimps were intramuscularly injected with sterile TN (negative control), WSSV (positive control), orWSSV pre-incubated with rMAP30 or BSA. The mortality was monitored daily for 15 days. (A) $70 \%$ mortality; WSSV injected. (B) $100 \%$ mortality;WSSV injected.

In the second set, mortality was first observed at 3 days post infection in the positive control group and the BSA-treated WSSV group, while mortality was observed 1 day later in the case of the rMAP30-treated WSSV group. Mortality in the case of rMAP30 was $60 \%$, which was significantly lower than that observed in the positive control group (100\% mortality) (Figure 2B).

In the present study, we determined the novel antiviral property of the protein MAP30 with regards to WSSV. For the WSSV challenge, different doses of WSSV were incubated with MAP30 and an intramuscular injection was adopted to ensure an equal challenge pressure. In both the WSSV challenge shrimps, the MAP30-incubated group showed significantly increased survival rates and delayed death from WSSV. The control group experienced high mortality. In the $70 \%$ mortality WSSV dose set, the protein showed higher relative survival rates $(85.5 \%)$ than that in the $90 \%$ mortality WSSV dose set $(60 \%)$.

\section{qPCR assay}

The antiviral activity of the MAP30 protein against WSSV was verified by quantification of the viral copy number. The viral DNA levels were quantitated with qRT-PCR analysis. The results showed that the recombinant MAP30 was significantly $(\mathrm{p}<0.001)$ able to inhibit the virus replication of $P$. clarkii in vivo, by reducing the viral copy number $\left(1.33 \pm 0.5 \times 10^{6}\right)$ compared with the untreated control $\left(5.57 \pm 0.2 \times 10^{6}\right)$. The DNA levels of MAP30-treated shrimps declined and cleared faster than the untreated shrimps (Figure 3 ). The results showed that MAP30 effectively inhibits WSSV proliferation in vivo. 


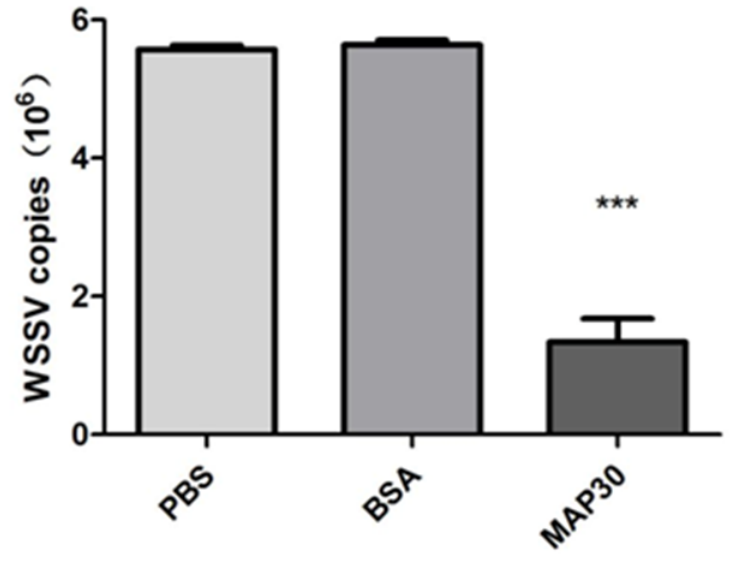

Figure 3 MAP30 inhibited WSSV infection.

\section{Immunological assays}

To evaluate the humoral immune response induced by rMAP30 in P.clarkii, the hemolymph samples were collected from different groups of shrimp and analyzed for various immunological parameters.

\section{Phenoloxidase (PO) activity}

In MAP30-injected shrimp, the PO activity increased significantly at $12 \mathrm{~h}$ post treatment when compared with the control group that was injected with PBS (Figure 4A). Phenoloxidase activity reached the highest level at $24 \mathrm{~h}$ post treatment. Following $24 \mathrm{~h}$, the PO activity began to decrease gradually and returned to the original levels at $72 \mathrm{~h}$.

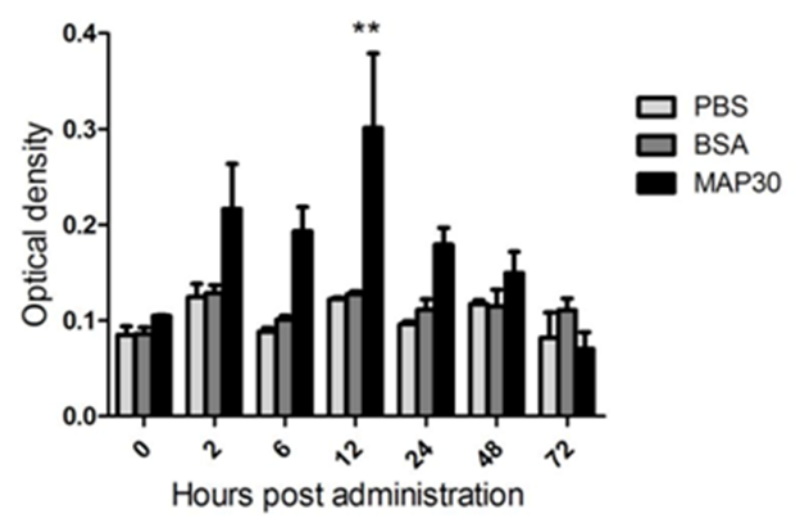

Figure 4 (A) Recombinant MAP30 (rMAP30) leads to PO activation in vivo. (B) Recombinant MAP30 (rMAP30) decreased superoxide dismutase activity in vivo. The error bar represents the standard deviation of mean $\pm \operatorname{SEM}(n=5)$. Asterisks or double asterisks indicate significant differences $(P<0.05$ and $P$ $<0.01$, respectively) compared with the control group that was injected with PBS and BSA.

\section{Superoxide dismutase (SOD) activity}

The SOD activity of MAP30-injected shrimp was significantly decreased compared with that of the negative control group at 2, 6, 12 , and 24 hours post-treatment, and a valley was observed at $6 \mathrm{~h}$. The SOD activity gradually increased back to its original level 3 days post administration (Figure 4B).
Prophenol oxidase (ProPO) and antioxidant defense systems are important components of the invertebrate humoral immune response. ${ }^{45}$ To further investigate the bioactivities of MAP30 in P. clarkii, the phenoloxidase and the SOD activities in the $P$. clarkii hemolymph were analyzed. After injection of MAP30, the PO activity increased quickly at $2 \mathrm{~h}$. The increase lasts until $72 \mathrm{~h}$ and reaches the highest level at $24 \mathrm{~h}$, indicating that proPO was induced by MAP30 in P. clarkii. We inferred that one way MAP30 may take part in WSSV and $V$. alginolyticus defense is by regulating humoral immune reactions. However, the activity of SOD in the serum of $P$. clarkii significantly declined following injection of MAP30, but MAP30 exhibited no SOD activity in vitro as well as in previous reports. ${ }^{46} \mathrm{We}$ propose that MAP30 may have an antioxidant capacity, and as expected, the protein was determined by the scavenging activity of hydroxyl radicals. Antioxidants may scavenge free radicals in shrimps. The decline of SOD in shrimp may associate with lower levels of free radicals in shrimps. In fact, during the production and the cleanup of free radicals in homeostasis in vivo, the presence of excessive free radicals can damage the organism. ${ }^{47}$

\section{Antioxidant capacity in vitro}

The antioxidant capacity of rMAP30 in vitro was measured by Fenton reaction that determines the scavenging activity of hydroxyl radicals. As shown in Figure 5, the OH-RSA of MAP30 increased with an increase in concentration, and the scavenging activity at $2 \mathrm{mg} /$ $\mathrm{mL}$ was $25 \%$. Thus, MAP30 displayed an antioxidant capacity and a scavenging activity of hydroxyl radicals.



Figure 5 Hydroxyl radical scavenging activity of MAP30. The control group is BSA.

\section{Topological inactivation}

To explore how this protein act on virus, we demonstrate the topological inactivation activity, supercoiled DNA (Litmus38i) and WSSV genome DNA were exposed to rMAP30, and DNA in the absence of rMAP30 was treated as a control. In suitable enzyme digestion conditions, rMAP30 cleaved the supercoiled doublestranded DNA to produce nicked circular or linear DNA. The genome DNA of the virus treated with rMAP30, was degenerated and the band obscured. As shown in Figure 6, rMAP30 exhibited DNaselike activity. Viral genome DNA and rRNA were degenerated after treatment with rMAP30. The DNA topological inactivation ability converts the DNA into topologically inactive forms that interrupt DNA function. ${ }^{48}$ MAP30 also has an N-glycosidase activity that acts on rRNA in a cell-free system. The ability of MAP30 to act on both DNA and RNA substrates may provide novel mechanisms for its antiviral actions. 




(A)



(B)
Figure 6 Topological inactivation activities. (A) Destruction of the WSSV genome DNA by rMAP30. Lane I - WSSV genome DNA as a control; Lanes 3-4 - the products of DNA with rMAP30; Lane M - DNA ladder; (B) rMAP30 cleaved the super coiled double-stranded DNA. Lane I - Litmus38i as a control; Lanes 2-5 - products of Litmus 38i DNA treated with different concentrations of rMAP30 $(0.8 \mathrm{mg}, 0.4 \mathrm{mg}, 0.2 \mathrm{mg}, 0.1 \mathrm{mg})$.

\section{Antimicrobial effects of rMAP30}

The results of the antimicrobial activity of rMAP30 are shown in Table 1 and Figure 7. Recombinant MAP30 showed antibacterial activity against Vibrio alginolyticus at a concentration of $700 \mu \mathrm{g} /$ $\mathrm{ml}$. The protein showed the effective inhibition towards Vibrio alginolyticus and the inhibition zones were more than $11 \mathrm{~mm}$ in diameter. The antimicrobial active principles of rMAP30 are still not clear, and the antimicrobial activation of MAP30 could be explored on other bacteria, it may be tested further to uncover their therapeutic potential in modern and traditional medicine against infectious diseases. It has much work to do explore the antimicrobial effects of rMAP30 in future.

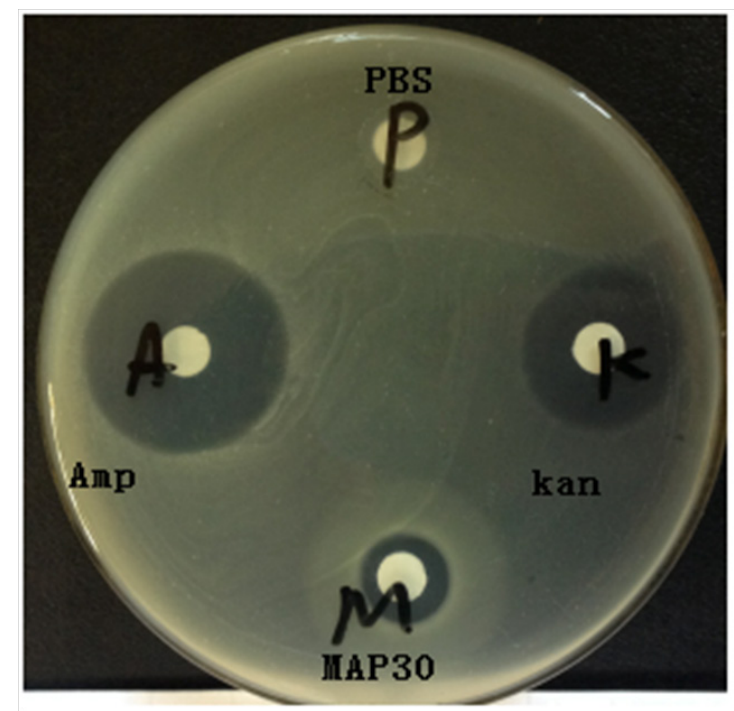

Figure 7 Inhibition zones of Vibrio alginolyticus;Amp,Ampicillin; Kan, kanamycin; PBS.

Table I Antimicrobial activity of rMAP30 based on a disc diffusion method (Zone of inhibition in $\mathrm{mm}$ )

\begin{tabular}{ll}
\hline Tested Microorganisms & V. alginolyticus \\
Zone of Inhibition & 11.10 \\
\hline
\end{tabular}

\section{Clearance of $V$. alginolyticus}

To examine whether MAP30 facilitates the subsequent clearance of $V$.alginolyticus, the shrimps were injected with $V$.alginolyticus that was pre-incubated with MAP30. Phosphate-buffered saline (PBS) and BSA were used as controls. As shown in Figure 8, V. alginolyticus was rapidly eliminated in all the 3 groups (PBS, BSA, rMAP30), and almost all the bacteria were cleared within $2 \mathrm{~h}$ after injection. While bacterial survival in the hemolymph of rMAP30-treated shrimp was significantly lower at $30 \mathrm{~min}$ post treatment than in the other 2 groups, this difference decreased over time. However, bacterial counts in the test group were still lower than those in the other groups, suggesting that rMAP30 facilitated the clearance of $V$.alginolyticus in shrimp. The antimicrobial assay reveals that MAP30 can inhibit the growth of $V$. alginolyticus in vitro. The clearance of V.alginolyticus in $P$. clarkii demonstrated that the residual counts of the V. alginolyticus preincubate with MAP30 in the P. clarkii haemolymph is significantly lower than that in the control group. This suggests that MAP30 can facilitate the clearance of $V$. alginolyticus in shrimp.



Figure $8 \mathrm{~V}$. alginolyticus clearance in vivo. The shrimps were injected with $V$. alginolyticus that were incubated with PBS, BSA, or rMAP30, as described in Section 2. The number of $V$. alginolyticus in $100 \mu \mathrm{L}$ hemolymph was determined by counting the plates. All the results represent the mean of 3 individual experiments. Asterisk indicates significant differences $(P<0.000 \mathrm{I})$.

\section{Conclusion}

Vibrio alginolyticus and WSSV are the most common and serious pathogens that have caused huge economic losses to shrimp aquaculture. V.alginolyticus often co-infects shrimp with WSSV. In the current study, we determined the new antiviral activity of the protein MAP30 with WSSV and the antimicrobial activity towards $V$. alginolyticus in P. clarkii. MAP30 facilitates the clearance of $V$. alginolyticus in $P$. clarkii, and shows antiviral activity against WSSV. The humoral immune reactions of $P$. clarkii are regulated by MAP30. Although further studies are needed to elucidate the molecular mechanisms, these results suggest that MAP30 may be a candidate for the prevention of WSSV and vibriosis.

\section{Acknowledgements}

The authors are thankful to State Key Laboratory of Virology, College of Life Sciences, Wuhan University and local shrimp farming.

\section{Conflicts of interset}

None.

\section{References}

1. Wonteerasupaya C, Vickers JE, Sriurairatana S, et al. A non-occluded, systemic baculovirus that occurs in cells of ectodermal and mesodermal origin and causes high mortality in the black tiger prawn Penaeus monodon. Diseases of aquatic organisms. 199521(1):69-77. 
2. Hossain MS, Chakraborty A, Joseph B, et al. Detection of new host for white spot syndrome virus of shrimp using nested polymerase chain reaction. Aquaculture. 2001;198(1-2):1-11.

3. Lo C-F, Ho C, Peng S, et al. White spot syndrome baculovirus (WSBV) detected in cultured and captured shrimp, crabs and other arthropods. $1996 ; 27: 215-225$.

4. Sánchez-Paz A. White spot syndrome virus: an overview on an emergent concern. Veterinary research. 2010;41(6):43

5. Wang Q, White BL, Redman RM, et al. Per os challenge of Litopenaeus vannamei postlarvae and Farfantepenaeus duorarum juveniles with six geographic isolates of white spot syndrome virus. Aquaculture. 1999; 170:179-194.

6. Chou H, Huang C, Wang C, et al. Pathogenicity of a baculovirus infection causing white spot syndrome in cultured penaeid shrimp in Taiwan. 1995;23:165-173

7. Escobedo-Bonilla CM, Alday-Sanz V, Wille M, et al. A review on the morphology, molecular characterization, morphogenesis and pathogenesis of white spot syndrome virus. J of fish dis. 200831(1):1-18.

8. Flegel TW. Major viral diseases of the black tiger prawn (Penaeus monodon) in Thailand. World Journal of Microbiology and Biotechnology. 1997;13(4):433-442.

9. Karunasagar I, Otta S, Karunasagar I. Histopathological and bacteriological study of white spot syndrome of Penaeus monodon along the west coast of India. Aquaculture. 1997;153(1-2):9-13.

10. Lightner D. Virus diseases of farmed shrimp in the Western Hemisphere (the Americas): a review. J invertebr pathol. 2011;106(1):110-130.

11. Rodríguez J, Bayot B, Amano Y, et al. White spot syndrome virus infection in cultured Penaeus vannamei (Boone) in Ecuador with emphasis on histopathology and ultrastructure. Journal of Fish Diseases. 2003;26:439-450

12. Kasornchandra J, Boonyaratpalin S, Itami T. Detection of white-spot syndrome in cultured penaeid shrimp in Asia: Microscopic observation and polymerase chain reaction. Aquaculture. 1998;164(1-4):243-251.

13. Lightner D. Epizootiology, distribution and the impact on international trade of two penaeid shrimp viruses in the Americas. Revue scientifique et technique (International Office of Epizootics). 1996;15(2):579-601.

14. Chang C-F, Su M-S, Chen H-Y, et al. Dietary $\beta-1$, 3-glucan effectively improves immunity and survival of Penaeus monodon challenged with white spot syndrome virus. Fish \& shellfish immunology. 2003;15:297310 .

15. Balasubramanian G, Sarathi M, Kumar SR, et al. Screening the antiviral activity of Indian medicinal plants against white spot syndrome virus in shrimp. Aquaculture. 2007;263(1-4):15-9.

16. Rameshthangam P, Ramasamy P. Antiviral activity of bis (2-methylheptyl) phthalate isolated from Pongamia pinnata leaves against White Spot Syndrome Virus of Penaeus monodon Fabricius. Virus research. 2007;126(1-2):38-44.

17. Li HX, Meng XL, Xu JP, et al. Protection of crayfish, Cambarus clarkii, from white spot syndrome virus by polyclonal antibodies against a viral envelope fusion protein. $J$ fish dis. 2005;28(5):285-291.

18. Chaivisuthangkura $\mathrm{P}$, Phattanapaijitkul $\mathrm{P}$, Thammapalerd $\mathrm{N}$, et al Development of a polyclonal antibody specific to VP19 envelope protein of white spot syndrome virus (WSSV) using a recombinant protein preparation. $J$ virol methods. 2006133(2):180-184.

19. Musthaq SS, Yoganandhan K, Sudhakaran R, et al. Neutralization of white spot syndrome virus of shrimp by antiserum raised against recombinant VP28. Aquaculture. 2006253(1-4):98-104.

20. Natividad KDT, Hagio M, Tanaka M, et al. White spot syndrome virus (WSSV) inactivation in Penaeus japonicus using purified monoclonal antibody targeting viral envelope protein. Aquaculture. 2007;269(14):54-62.
21. Wu J, Nishioka T, Mori K, et al. A time-course study on the resistance of Penaeus japonicus induced by artificial infection with white spot syndrome virus. Fish shellfish immunol. 2002;13:391-403.

22. Namikoshi A, Wu JL, Yamashita T, et al. Vaccination trials with Penaeus japonicus to induce resistance to white spot syndrome virus. Aquaculture. 2004;229(1-4):25-35.

23. Witteveldt J, Vlak JM, van Hulten MC. Protection of Penaeus monodon against white spot syndrome virus using a WSSV subunit vaccine. Fish \& shellfish immunology. 2004;16(5):571-579.

24. Jha RK, Xu ZR, Shen J, et al. The efficacy of recombinant vaccines against white spot syndrome virus in Procambarus clarkii. Immunology letters. 2006105(1):68-76.

25. Rout N, Kumar S, Jaganmohan S, et al. DNA vaccines encoding viral envelope proteins confer protective immunity against WSSV in black tiger shrimp. Vaccine. 2007;25(15):2778-2786.

26. Kumar SR, Ahamed VI, Sarathi M, et al. Immunological responses of Penaeus monodon to DNA vaccine and its efficacy to protect shrimp against white spot syndrome virus (WSSV). Fish \& shellfish immunology. 2008;24(4):467-478.

27. Westenberg M, Heinhuis B, Zuidema D, et al. siRNA injection induces sequence-independent protection in Penaeus monodon against white spot syndrome virus. Virus research. 2005;114:133-139.

28. Kim CS, Kosuke Z, Nam YK, et al. Protection of shrimp (Penaeus chinensis) against white spot syndrome virus (WSSV) challenge by double-stranded RNA. Fish \& shellfish immunology. 2007;23(1):242246

29. Xu J, Han F, Zhang X. Silencing shrimp white spot syndrome virus (WSSV) genes by siRNA. Antiviral research. 2007;73(2):126-31.

30. Wu Y, Lü L, Yang L-S, et al. Inhibition of white spot syndrome virus in Litopenaeus vannamei shrimp by sequence-specific siRNA. Aquaculture. 2007271(1-4):21-30

31. Sarathi M, Simon MC, Ahmed VI, et al. Silencing VP28 gene of white spot syndrome virus of shrimp by bacterially expressed $d s R N A$. Marine biotechnology. 2008;10(2):198-206.

32. Lee-Huang S, Huang PL, Nara PL, et al. MAP 30: a new inhibitor of HIV-1 infection and replication. FEBS letters. 1990;272(1-2):12-8.

33. Bourinbaiar AS, Lee-Huang S. The Activity of Plant-Derived Antiretroviral Proteins MAP30 and GAP31 against Herpes Simplex Virus Infectionin Vitro. Biochem biophys res commun. 1996;219(3):923929.

34. Sun Y, Huang PL, Li JJ, et al. Anti-HIV agent MAP30 modulates the expression profile of viral and cellular genes for proliferation and apoptosis in AIDS-related lymphoma cells infected with Kaposi's sarcoma-associated virus. Biochem Biophys res commun. 2001;287(4):983-994.

35. RYBAK SM, Lin J, Newton D, et al. (1994) In-vitroantitumor-activity of the plant ribosome-inactivating proteins MAP-30 and GAP-31. Int $j$ Oncol 5(5): 1171-1176.

36. Lee-Huang S, Huang P, Sun Y, Chen H, Kung H, et al. (1999) Inhibition of MDA-MB-231 human breast tumor xenografts and HER2 expression by anti-tumor agents GAP31 and MAP30. Anticancer research 20: 653659.

37. Lee-Huang S, Huang PL, Chen H-C, Huang PL, Bourinbaiar A, et al. (1995) Anti-HIV and anti-tumor activities of recombinant MAP30 from bitter melon. Gene 161(2): 151-156.

38. Fan J-M, Luo J, Xu J, Zhu S, Zhang Q, et al. (2008) Effects of recombinant MAP30 on cell proliferation and apoptosis of human colorectal carcinoma LoVo cells. Mol biotechnol 39(1): 79-86. 
39. Sanjuktha M, Rajan J, Bharathi RA, Santiago T, Alavandi S, et al. (2014) Development of SYBR Green based real time PCR assay for detection of monodon baculovirus in Penaeus monodon. J virol methods 205: 816.

40. Wang X-W, Zhang H-W, Li X, Zhao X-F, Wang J-X (2011) Characterization of a C-type lectin (PcLec2) as an upstream detector in the prophenoloxidase activating system of red swamp crayfish. Fish \& shellfish immunology 30: 241-247.

41. Halliwell B, Gutteridge JM, Aruoma OI (1987) The deoxyribose method: a simple "test-tube" assay for determination of rate constants for reactions of hydroxyl radicals. Analytical biochemistry 165: 215219.

42. Desmarchelier C, Coussio J, Ciccia G (1998) Antioxidant and free radical scavenging effects in extracts of the medicinal herb Achyrocline satureioides (Lam.) DC.(“marcela”). Braz J Med Biol Res 31(9): 11631170

43. Seydim A, Sarikus G (2006) Antimicrobial activity of whey protein based edible films incorporated with oregano, rosemary and garlic essential oils. Food research international 39(5): 639-644.
44. Wang X-W, Zhang X-W, Xu W-T, Zhao X-F, Wang J-X (2009) A novel C-type lectin (FcLec4) facilitates the clearance of Vibrio anguillarum in vivo in Chinese white shrimp. Dev Comp Immunol 33(9): 1039-1047.

45. Roch P (1999) Defense mechanisms and disease prevention in farmed invertebrates. Aquaculture 172(1-2): 125-145.

46. Meng Y, Lin S, Liu S, Fan X, Li G, et al. (2014) A Novel Method for Simultaneous Production of Two Ribosome-Inactivating Proteins, $\alpha$-MMC and MAP30, from Momordica charantia L. PloS one 9(7): e101998.

47. Yu BP (1994) Cellular defenses against damage from reactive oxygen species. Physiol. Rev 74(1): 139-162.

48. Lee-Huang S, PL Huang, HC Chen, PL Huang, A Bourinbaiar, et al. (1995) Anti-HIV and anti-tumor activities of recombinant MAP30 from bitter melon. Gene 161(2): 151-156. 